\title{
Rewriting Dalit Gender Paradigms through the Viranganas and Femme Fatale Archetypes
}

\section{Arsha Subbi $^{1}$ and Dr Balakrishnan Kalamullathil ${ }^{2}$}

${ }^{1}$ Department of English and Languages, Amrita Viswa Vidyapeetham, Kochi Campus, India

Orcid ID:https://orcid.org/0000-0002-4944-8872

${ }^{2}$ Department of English and Languages, Amrita Viswa Vidyapeetham, Kochi Campus, India.

Orcid ID: https://orcid.org/0000-0002-4577-8399

*Corresponding Author email id: ${ }^{1}$ arshasubbi@gmail.com,

D.O.I - $10.51201 / \mathrm{JUSST} / 21 / 05180$

http://doi.org/10.51201/JUSST/21/05180 


\begin{abstract}
The true identity of the Femme Fatale character type has not yet been discovered despite the growing interest of authors and writers in this lethal woman archetype, whose extensive presence was seen in nineteenth and twentieth century literary and cultural texts. The Femme Fatale has acquired numerous forms since her arrival into the literary arena. Although typically villainous, or at least morally confusing, and always associated with a sense of mystification and unease, Femme Fatales have also appeared as an anti-heroine in some stories. Some narratives also end with a repenting Femme Fatale, who regrets her past villainy. Some Femme Fatales also pave way for greater good by ensnaring the villain and reforming him through her lethal treatments. Dalit viranganas are a group of warrior women characters who are comparatively novel portrayals within the arena of literature. These characters refurbish the entire ideologies governing the conventional patriarchy which often put women under the control of these patriarchal figures. She denies fitting into the roles of a dutiful wife and nurturing mother that the mainstream society prescribes for her. In these representations there is a blending of history and present and these women become symbols of pride for the community. They are often dressed in masculine manner and displays physical prowess, which is a quality often ascribed to men. She leaves behind a strong picture of an unremorseful, bold and daring woman who adheres to her own ideals rejecting the rules put forward by society.
\end{abstract}

Keywords: Femme Fatales, Dalit Viranganas, Patriarchy, Dalit Feminism, Femininity, Gender order, Gender theories, Feminism. 
Patriarchy is when a male figure holds control over the functioning of a whole system, be it a society or an individual household. It refers to a social mechanism that glorifies male dominance over women. Culture repositioning is a method suggested by feminists in the process of deconstructing patriarchy. Culture repositioning refers to changing of a culture. Feminist critics often use the terms, 'male chauvinism' and 'sexism', instead of the term 'patriarchy'. The terms roughly refer to the same phenomenon. Author Bell Hooks argues that the new term identifies the ideological system itself that men are inherently dominant or superior to women, which can be believed and acted upon by either men or women, whereas the earlier term implies that only men act as oppressors of women.

A gender stereotype is more of a general concept that incorporates a number of qualities or features that are expected to be possessed by women. It becomes a harmful misconception when these stereotypes limit the abilities and aspirations of a woman. Harmful stereotypes can be both hostile and negative, like, "women are irrational” or seemingly compassionate, for example, "women are nurturing”. It is a common misconception that child rearing responsibilities solely fall on women alone.

These gender stereotyping effects the society in an adverse manner, where oppressions faced by the women community gets buried within the patriarchal structure of rules and regulations. For example marital rape is still an existing evil in society only because of the societal perception of women being a physical possession owned by men. Women are forced to stay within the ascribed norms and patterns. This amalgamation of gender norms leads to unfair conditions for certain faction of women like women from marginal categories, migrant women, women with disabilities etc. 
The patterns created through the emanating structures of ideologies and human practices ultimately create biased power relations between the male and female categories. This process is repeated and altered as per the changing notions and ideals in this fast pacing society. Society never remains the same and keeps adding new values and notions. The ideologies especially those that specifically relate to gender, create the notions of masculinity and femininity. These concepts are created and determine the power hierarchies in the society. Power structures are created and variations are formed within the society, thus leading to situations of inequity and bigotry. Though patriarchy dominates the arena of gender reality, this isn't the only factor that drives the gender concepts to its new ends. Gender hierarchies could also be democratic or even run by the concepts of matriarchy. The excess of attention and significance given to patriarchy in the study of gender studies often diminishes the other diminutive factors. The concept of gender order which was primarily discussed by Jill Mathews(1984) bestows special attention to the historic construction of femininity. Gender order theories generally embosom the concepts of universality and equity, recognizing the dominant and also subservient elements within the concept of gender order. The concepts of gender order also recognize the need to stop portraying men and women according to the existing patriarchal ideologies. For example women, in most of the texts discussing discriminatory attitudes get portrayed as the submissive and obedient recipient of violence rather than ones who react against it or move beyond the boundaries prescribed to them, which if attempted would allow the possibility of social change.

Dalit feminism is one of the growing trends that seek to follow this trend prescribed by the gender order theories. Rabindranath Tagore addresses the dalit heroine, Prakriti in Chandalika, who was bewitched by the good looks of the Buddhist monk Ananda, due to which she urges her mother to perform occult practices to lure him to her. This eventually leads to the 
death of Prakriti's mother .The remorse and guilt drives Prakriti to seek the blessings and forgiveness of Ananda, which later lets her off the clutches of guilt and remorse.

Indian literature and the representation of different castes in these literary works is an important area of study in many discussions pertaining to indigenous characters. There have been significant amount of theoretical studies that are concerned the way actuality is represented in these pieces of literature. Reality is often twisted and altered in the process of retelling the histories of various castes and sections. These studies also analyze the way high caste and middle class women were portrayed in mainstream literature, particularly during the colonial period. Dalit women belong to those categories of women who are often forgotten in these studies. Mainstream literature and theoretical studies fail to consider dalit women within the category of "women", and their struggles, realities and representations never received momentum until only recently. Characterization and portrayal of dalit women specifically during and post colonial period, within the early mainstream feminist discourses were left negligible and merely in the suburbs of discussions. Dalit literary works of 1857 supplies an alternative and progressive account of dalit community, especially women. These representations provide a completely altering light into the characterization of dalit women in literature. This not only provides an altered perspective of gender politics, but also gives special importance to the struggles and atrocities faced by the dalits thereby rendering a diverse meaning to their struggle . Dalit women viranganas were the warrior women characters who played an important part in the revolts of 1857.The highlighting of these warrior women characters or viranganas rewrites the entire constitution of Dalit individuality and identity. This representation effectively redoes the biased textual representations of these dalit women characters as merely submissive. It provides a simultaneous account of academic, historical and textual narratives of 1857 . The negative female 
archetypes like the femme fatales or warrior women can be labeled as manifestations of resistance to dominant discourses about dalit women. These Dalit women viranganas materialize these alternative female personalities as noticeable and titular characters, and objects of adulation and prominence.

The true identity of the Femme Fatale character type has not yet been discovered despite the growing interest of authors and writers in this lethal woman archetype whose extensive presence was seen in nineteenth and twentieth century literary and cultural texts. The Femme Fatale has acquired numerous forms since her arrival into the literary arena. She is the Egyptian Sphinx, half-human, half-animal. She is the Bible's teenage seductress Salome. She is the devious World War I spy Mata Hari. She is the evil Queen in Snow White (1812). She is the Egyptian Queen Cleopatra, the Roman empress Messalina, the much maligned Renaissance princess Lucrezia Borgia, and the misunderstood second wife of English King Henry VIII, Anne Boleyn. These women and many other women have been tagged evil by male historians and critics only because they have displayed power and control much alike their male counterparts. A Femme Fatale does not fit to the identity unless she makes the male characters around her yield their powers before her. They are tortured by her in all means possible.

Virginia Allen, an American educationalist in her attempt to trace back the origin of the term 'Femme Fatale', discovers that its usage dates back to the 1900s, even though writers made use of the character type before 1900.Virginia Allen also speculates that the term must have been coined in popular journalism. Though the term has a French trace, this does not necessarily mean that the French invented the term. Mario Praz, an Italian critic of art and Literature devotes a whole chapter of The Romantic Agony (1933) to the Femme Fatale figures in literary works. Praz stated in his work that this fatal female figure has made her appearance since early literary texts 
and mythologies. Praz evaluated each of these figures so as to provide some consistent traits of this fatal woman.

In the early works of art the Femme Fatale was often portrayed as a preying mantis, a vampire, a siren or a wanton courtesan. Praz states that the Femme Fatale was an exotic and irresistible figure. He mentions her youth, sexual cannibalism and inexperience of her lovers. Patrick Bade, writing in 1979, likewise does not attempt to define the term in detail and describes the Femme Fatale as 'malignant, threatening, destructive and fascinating'. Although typically villainous, or at least morally confusing, and always associated with a sense of mystification and unease, Femme Fatales have also appeared as an anti-heroine in some stories, and some even repent and become true heroines by the end of the tale. Some Femme Fatales also pave way for greater good by ensnaring the villain and reforming him through her lethal treatments.

The Femme Fatale archetype refurbishes the entire ideologies governing the conventional patriarchy which often put women under the control of these patriarchal figures. She denies fitting into the roles of a dutiful wife and nurturing mother that the mainstream society prescribes for her. She finds marriage to be confining, loveless and dull, and her wildness and sexual magnetism is put into use to help herself out of this muddle. She nevertheless persists even at the face of her own annihilation. And despite her ultimate punishment of death, she leaves behind the strong picture of an unremorseful, bold and daring woman who adheres to her own ideals rejecting the rules put forward by men or the society .She is also the one who rejects the institution of the family. Murder is the weapon made use by a classic Femme Fatale and she often uses it to free herself from the clutches of an excruciating marriage or a relationship, where she is given the meager value of a property or pet. Marriage for the Femme Fatale represents unhappiness, boredom, and the absence of romantic love and sexual desire. A certain kind of 
myth is generated within the society rendering the family home as the center of safety, fulfillment, and love. The benefits normally associated with marriage and the families especially in the conventional romantic fiction are actually absent in reality.

The Femme Fatale character type has made a recurring presence in both high and popular culture; however she is also a perpetual site of unpredictability, paving way for further investigation. Thus the Femme Fatale is recognized as both indelible cultural stereotype and never completely knowable. She is always beyond definition. This conundrum and a disguised identity always lying above the actual character, is a persistent element in the critical discussions of the Femme Fatale.

The actual root of Femme Fatale characterization lies across cultures and ages. This complicated female figure has emanated as a result of extensive exploration of the transnational and historical works. It is important to evaluate each version of Femme Fatales based on its relation to its local background and culture, as well as in relation to the ways it may have absorbed other traditional representations.First, the Femme Fatale’s actions and motivations are ones that break down the gender code, and the second is that the depiction of the Femme Fatale has evolved in art and literature over time, to which the motivations, even the ending of the character's actions, have changed drastically. Therefore, the Femme Fatale attains an important place in today's fictional world as it did during the earlier times.

To limit the readings of female dalit representation to their subjugations and marginalization alone would not provide the whole picture of their existence. Oftentimes reality gets subjugated within the mainstream renderings of history. These warrior female figures have the capability to rewrite conventional hegemonic narratives and provide an alternative perspective about dalit women and also about the history they were part of. The representation of 
dalit viranganas on a high moral and heroic ground can also be seen as an appropriation of respectability and "credibility", imparting dalit participation in past histories new meanings. These dalit viranganas represent dalits in the service of freedom and Indian nationalism.

These female characters clearly refute the notions of Spivak regarding the lack of subaltern voice and here they are speaking through these dalit women viranganas. There is a clear representation of their own voices. These strong female characters dare to question the conventional notions of gender, both about the history and the part played by dalit women. While the credibility and authenticity of the accounts within these narratives and archetypes need to be questioned, it provides these long subjugated characters a platform to reformulate their tales all by themselves and also their identities. Dalit women occupy the position of signifiers of 1857 and also of general dalit identity. Dalit viranganas not only provide voice to the female category alone but also for all Dalits. These perpetually brave women retell the legacy and history of their creed, not limiting themselves within the marginalized corners of historical and gender identity.

\section{References:}

Mainon, Dominique and James Ursin. Femme Fatale: Cinema's Most Unforgettable Lethal Ladies. Limelight publishers,2009.

Allen, Virginia. The Femme Fatale: Erotic Icon. Whitson Publishing Company,1983. Gupta,Charu. Dalit 'Viranganas' and Reinvention of 1857. Economic and Political Weekly, Vol. 42, No. 19 (May 12-18, 2007), pp. 1739-1745

Doane, Mary Ann. Femme Fatale.Routledge publishers, 1991.

Jardine, Alice and Paul Smith. Men in Feminism. Methuen publishers,1987.

Doane,M.A.Femme Fatales:Feminism,Film Theory,Psychoanalysis.Routledge,1991.

Praz,Mario.The Romantic Agony.Oxford UP,1970. 